\title{
EFEKTIVITAS E-LEARNING MADRASAH DALAM PEMBELAJARAN BIOLOGI DI MAN 3 JOMBANG
}

\author{
ARINI RAHMA DHANI \\ MAN 3 Jombang \\ e-mail: arinirahmadhani21@gmail.com
}

\begin{abstract}
ABSTRAK
Pandemi Covid-19 berdampak terhadap proses belajar mengajar yang harus dilakukan secara jarak jauh (daring), untuk melindungi keselamatan dan kesehatan peserta didik dariancaman Covid-19. MAN 3 Jombang sebagai salah satu lembaga pendidikan dasar dibawah Kementerian Agama mengambil keputusan untuk memanfaatkan aplikasi e-learning madrasah yang digunakan dalam pembelajaran jarak jauh. Peserta didik MAN 3 Jombang sebagian besar merupakan santri di lingkungan Pondok Pesantren Bahrul Ulum. Faktor pendukung dan penghambat pembelajaran jarak jauh dalam jaringan (daring) tentunya juga berbeda dari sekolah/madrasah lainnya. Tujuan penelitian ini untuk mengetahui efektivitas pelaksanaan pembelajaran jarak jauh dalam jaringan (daring) melalui $e$-learning madrasah pada mata pelajaran Biologi serta apa saja faktor pendukung dan penghambat efektivitas pembelajaran jarak jauh dalam jaringan (daring). Penelitian ini termasuk dalam penelitian kuantitatif deskriptif. Berdasarkan angket peserta didik dengan tiga aspek yakni aspek motivasi, kemudahan, dan kegunaan. Pembelajaran jarak jauh dalam jaringan (daring) melalui e-learning madrasah pada mata pelajaran Biologi pada aspek motivasi didapatkan presentase rata-rata sebesar $84,8335 \%$, pembelajaran jarak jauh dalam jaringan (daring) melalui $e$ learning madrasah pada mata pelajaran Biologi pada aspek kemudahan didapatkan persentase ratarata sebesar $81,5567 \%$ sedangkan untuk aspek kegunaan didapatkan persentase rata-rata sebesar $81,335 \%$. Efektifitas pembelajaran jarak jauh dalam jaringan (daring) melalui e-learning madrasah dari segi guru dinilai dari dua aspek yakni aspek kemudahan dengan persentase rata-rata sebesar 80\% dan aspek kegunaan sebesar, dan aspek kegunaan persentase rata-rata sebesar 79,2\%. Sehingga pembelajaran menggunakan e-learning madrasah pada mata pelajaran Biologi tergolong efektif.
\end{abstract}

Kata Kunci: efektivitas, e-learning madrasah, pembelajaran Biologi

\section{PENDAHULUAN}

Sejak Maret 2019 wabah Corona Virus Deseases melanda Indonesia. Kebijakan pemerintah untuk menekan penyebaran Covid-19 dengan memberhentikan pembelaaajaaran tatap muka dan memberlakukan pembelajaran jarak jauh. Kementerian Pendidikan dan Kebudayaan (Kemendikbud) menerbitkan Surat Edaran Nomor 15 Tahun 2020 tentang Pedoman Penyelenggaraan Belajar Dari Rumah Dalam Masa Darurat Penyebaran Covid-19. Dalam surat edaran tersebut disebutkan bahwa tujuan dari pelaksanaan Belajar Dari Rumah (BDR) adalah memastikan pemenuhan hak peserta didik untuk mendapatkan layanan pendidikan selama darurat Covid-19, melindungi warga satuan pendidikan dari dampak buruk Covid-19, mencegah penyebaran dan penularan Covid-19 di satuan pendidikan dan memastikan pemenuhan dukungan psikososial bagi pendidik, peserta didik, dan orang tua.

Kemendikbud menganjurkan bahwa aktivitas pembelajaran Belajar Dari Rumah (BDR) dapat bervariasi antar daerah, satuan pendidikan dan peserta didik sesuai minat dan kondisi masingmasing. Aktivitas pembelajaran Belajar Dari Rumah (BDR) juga mempertimbangkan kesenjangan akses terhadap fasilitas. Metode dan media pelaksanaan Belajar Dari Rumah (BDR) dapat dilaksanakan dengan dengan pembelajaran jarak jauh dengan pendekatan pembelajaran jarak jauh dalam jaringan (daring) ataupun luar jaringan (luring), yang dapat disesuaikan dengan kondisi 
instutisi pendidikan. Hal ini menyebabkan Intitusi harus memilih dan memilah aplikasi yang dapat mendukung dalam pelaksanaan pembelajara jarak jauh.

Berbagai macam alternatif aplikasi pembelajaran jarak jauh dalam jaringan (daring) menjadi pilihan bagi guru untuk melakukan komunikasi yang intens dengan peserta didik, diantaranya menggunakan Google Classroom, Microsoft Office 365, Schoology dan masih banyak aplikasi pembelajaran online yang bisa dipilih untuk menjamin keberlangsungan proses belajar mengajar. Penguasaan teknologi, informasi dan komunikasi penting bagi guru agar dapat menjamin terlaksananya proses belajar mengajar bagi peserta didik secara daring. Salah satu media perantara antara peserta didik dan guru agar dapat memantau perkembangan belajar peserta didik adalah dengan penggunaan e-learning. E-learning adalah aplikasi berbasis internet yang dapat dengan mudah menghubungkan siswa dan guru dalam suatu aplikasi ruang belajar online. Desain $e$ learning bertujuan untuk dapat mengatasi segala keterbatasan guru dan siswa dalam proses pelaksanna pembelajaran terutama dalam hal waktu, keadaan, dan ruang (Mustakin, 2020).

Kementerian Agama Republik Indonesia menyediakan media pembelajaran online yakni $e$ learning madrasah. E-learning Madrasah adalah sebuah aplikasi gratis produk Madrasah yang ditujukan untuk menunjang proses pembelajaran di Madrasah dari mulai Raudatul Athfal (RA), Madrasah Ibtidayah (MI), Madrasah Tsanawiyah (MTs) dan Madrasah Aliyah (MA), agar lebih terstruktur, menarik dan interaktif. MAN 3 Jombang sebagai salah satu lembaga pendidikan dasar dibawah Kementerian Agama mengambil keputusan untuk memanfaatkan aplikasi e-learning madrasah yang digunakan dalam pembelajaran jarak jauh.

Peserta didik MAN 3 Jombang memiliki karakteristik yang berbeda beda, hal ini disebabkaan 90 persen peserta didik berasal dari daerah di seluruh Indonesia. Pesertaa didik tidak hanya bersekolah namun juga menjadi santri di pondok-pondok yang ada di lingkungan Pondok Pesantren Bahrul Ulum. Faktor pendukung dan penghambat pembelajaran jarak jauh dalam jaringan (daring) tentunya juga berbeda dari sekolah/madrasah lainnya. MAN 3 Jombang berupaya agar pembelajaran jarak jauh dalam jaringan (daring) dapat berjalan dengan baik dan efektif. Penggunaan pembelajaran daring akan menjadi sangat efektif jika memenuhi komponen esensial dalam pembelajaran yaitu diskusif, adaptif, interaktif, dan reflektif dengan elemen-elemen yang akan sangat baik jika diintegrasikan dengan lingkungan pembelajar sehingga dapat menjadi pembelajaran daring yang terintegrasi dengan lingkungan atau memenuhi komponen digital learning ecosystem (Oktavian \& Aldyan, 2020). Menurut Wicaksono (2011) Suatu pembelajaran dikatakan efektif apabila memenuhi ciri-ciri sebagai berikut: a) dapat mengembangkan pemahaman siswa terhadap materi belajar, b) membuat siswa menjadi memiliki rasa ingin tahu, c) membuat siswa menjadi tertantang, d) dapat membuat siswa aktif secara mental, fisik dan psikis, e) membantu siswa tumbuh kreatif, f) mudah dilaksanakan oleh guru.

Mata pelajaran Biologi memerlukan pembelajaran yang konstektual dan konkret. Pengalaman langsung siswa didapatkan dengan pembelajaaran berbasis praktikum. Adanya kebijakan pembelajaran yaang dilakukan dengan menggunakan $e$-learning madrasah ini, menuntut guru agar lebih menghadirkan pengalaman belajar yang menarik dan efektif. Berdasarkan penelitian yang dilakukan oleh Sutini, dkk (2020) pembelajaran daring menggunakan e-learning madrasah pada mata pelajaran Matematika dinilai efektif. Sejalan dengan penelitian yang dikemukakan oleh Hikmah (2020) penggunan aplikasi e-learning madrasah untuk pembelajaran jarak jauh di MIN 1 Rembang selama bulan Agustus terbukti efektif serta bisa diterima dan diikuti oleh peserta didik. Berdasarkan pemaparan tersebut tujuan dari penelitian ini adalah untuk mengetahui tingkat efektifitas pembelajaran jarak jauh dalam jaringan (daring) dengan menggunakan e-learning madrasah pada mata pelajaran Biologi di MAN 3 Jombang. Adapun rumusan masalah dalam penelitian ini bagaimana efektivitas pelaksanaan pembelajaran jarak jauh dalam jaringan (daring) melalui e-learning madrasah pada mata pelajaran Biologi serta apa saja faktor pendukung dan penghambat efektivitas pembelajaran jarak jauh dalam jaringan (daring). 


\section{METODE PENELITIAN}

Penelitian ini termasuk dalam penelitian kuantitatif deskriptif. Subyek penelitian dalam penelitian ini adalah siswa dan guru pengampu mata pelajaran Biologi di MAN 3 Jombang. Teknik pengambilan responden dilakukan dengan teknik simple random sampling. Jumlah responden terdiri dari 30 peserta didik yang terdiri dari 3 jenjang kelas X, XI, dan XII dan 5 guru Biologi. Penelitian ini dilakukan pada semester 1 tahun ajaran 2021/2022. Teknik pengumpulan data dilakukan melalui pemberian kuesioner dan wawancara secara online melalui google form. Kuesioner digunakan untuk mengukur efektivitaas E-learning madrasah melalui pertanyaan dengan menggunakan skala Likert. Teknik analisis data dalam penelitian ini menggunakan teknik analisis statistik deskriptif. Data diolah berdasarkan jawaban yang diberikan responden terhadap pernyataan dari setiap item kuesioner. Setelah data dari seluruh responden terkumpul, maka peneliti melakukan pengelompokkan, pengurutan, pengkategorian dan perhitungan untuk menjawab rumusan masalah.

\section{HASIL DAN PEMBAHASAN}

Hasil

Berdasarkan angket yang telaah diisi oleh siswa, terdapat 3 aspek yang diukur dalam menemtukan efektifitas pelaksanan pembelajaaraan jarak jauh dalam jaringn (daring) melalui $e$ learning madrasah yakni aspek motivasi, indikator kemudahaan untuk digunakan, dan aspek manfaat atau kegunaan dari pembelajaran e-learning madrasah pada mata pelajaran Biologi. Berikut ini tabel distribusi jawaban yang diperoleh dari angket peserta didik.

\section{Tabel 1. Perhitungan Presentase Aspek Motivasi}

\begin{tabular}{|c|c|c|c|c|c|c|c|c|}
\hline \multirow[b]{2}{*}{ Aspek Motivasi } & \multicolumn{6}{|c|}{ Skor } & \multirow{2}{*}{$\begin{array}{l}\text { Persentase } \\
\%\end{array}$} & \multirow{2}{*}{$\begin{array}{l}\text { Rata- } \\
\text { rata } \%\end{array}$} \\
\hline & SS & $\mathbf{S}$ & KS & TS & STS & Total & & \\
\hline $\begin{array}{l}\text { Saya percaya diri dapaat menggunakan } e \text { - } \\
\text { learning madrasah }\end{array}$ & 17 & 13 & 0 & 0 & 0 & 137 & 91.333 & \\
\hline $\begin{array}{l}\text { Saya percaya diri dapat mengoperasikan isi } \\
\text { dan fiture e-learning madrasah }\end{array}$ & 12 & 18 & 0 & 0 & 0 & 132 & 88 & \\
\hline $\begin{array}{l}\text { Saya senang belajar menggunakan e-learning } \\
\text { madrasah }\end{array}$ & 10 & 13 & 7 & 0 & 0 & 123 & 82 & 84.83325 \\
\hline $\begin{array}{l}\text { Saya termotivasi dengan belajar } \\
\text { menggunakan } \text { e-learning madrasah dalam } \\
\text { mata pelajaran Biologi }\end{array}$ & 4 & 16 & 9 & 1 & 0 & 117 & 78 & \\
\hline
\end{tabular}

Berdasarkan Tabel 01 menunjukkan rata-rata aspek motivasi sebesar 84,83\% yang peserta didik termotivasi dalam pembelajaran jarak jauh dalam jaringan (daring) pada mata pelajaran Biologi. Rata-rata peserta didik percaya diri dan senang dalam penggunaan e-learning madrasah. Menurut Entika (2019) motivasi belajaar ditunjukkaan dengaan harga diri ataau konsep belajar yang dicermikan daari sikap, tujuan, keterlibataan peseerta didik dalam pengalaman pembelajaran sehingga muncul peserta didik yang tertarik dalam belajar dan mempereroleh pengetahuan yang baru.

Tabel 2. Tabel Perhitungan Presentase Aspek Kemudahan

\begin{tabular}{lcccccccc}
\hline & \multicolumn{1}{c}{ Skor } & & \multicolumn{2}{c}{ Rata-rata } \\
\cline { 2 - 6 } \multicolumn{1}{c}{ Aspek Kemudahan } & SS & S & KS & TS & STS & TOTAL & Persentase\% & \% \\
\hline $\begin{array}{l}\text { E-learning madrasah mudah } \\
\text { dioperasikan/digunakan }\end{array}$ & 12 & 16 & 2 & 0 & 0 & 130 & 86.667 & \\
$\begin{array}{l}\text { E-learning madrasah memudahkan saya } \\
\text { mengakses informasi yang diberikan guru }\end{array}$ & 9 & 19 & 2 & 0 & 0 & 127 & 84.667 & 81.555667 \\
$\begin{array}{l}\text { E-learning madrasah sesuai dengan gaya } \\
\text { belajar saya. }\end{array}$ & 3 & 16 & 11 & 0 & 0 & 110 & 73.333 \\
\hline
\end{tabular}


Tabel 2 menunjukkan bahwa rata-rata persentase aspek kemudahan dalam penggunaan $e$ learning madrasah dalam pembelajaran jarak jauh dalam jaringan (daring) pada mata pelajaran Biologi tergolong baik, dengan nilai 81,55\%. E-learning madrasah mudah diopearasikan, memudahkan siswa mengakses informasi yang diberikan guru.

Tabel 3. Tabel Perhitungan Presentase Aspek Kegunaan

\begin{tabular}{lcccccccc}
\hline & \multicolumn{1}{c}{ Skor } & & Persentase & Rata- \\
\cline { 2 - 8 } & Aspek Kegunaan & S & KS & TS & STS & TOTAL & \% & rata \% \\
\hline $\begin{array}{l}\text { E-learning madrasah memudahkan belajar } \\
\text { saya }\end{array}$ & 7 & 17 & 6 & 0 & 0 & 121 & 80.667 & \\
$\begin{array}{l}\text { E-learning madrasah memfasilitasi interaksi } \\
\text { dan komunikasi antara peserta didik dan guru }\end{array}$ & 5 & 16 & 7 & 0 & 0 & 118 & 78.667 & 81.3335 \\
$\begin{array}{l}\text { E-learning madrasah membuat saya nyaman } \\
\text { dalam belajar }\end{array}$ & 4 & 16 & 10 & 0 & 0 & 114 & 76 \\
$\begin{array}{l}\text { E-learning madrasah memungkinkan saya } \\
\text { untuk mengirim tugas dan mengerjakan test }\end{array}$ & 15 & 15 & 0 & 0 & 0 & 135 & 90 \\
\hline
\end{tabular}

Tabel 3 menunjukkan bahwa pembelajaran jarak jauh melalui e-learning madrasah pada mata pelajaran Biologi termasuk berguna atau bermanfaaat bagi peserta didik di saat pandemi Covid 19 ini. Hal ini dikarenakan e-learning madrasah memudahkaan dalam pembelajaran, memfaasititasi interaksi antara peserta didik dan guru, nyamaan, terdapat fitur-fitur menggunggah tugas dan peserta didik dapat mengakses tes dengan mudah.

Pada penelitian ini guru juga mengisi angket terdapat 3 aspek yang diukur dalam menemtukan efektifitas pelaksanan pembelajaran jarak jauh dalam jaringan (daring) melalui e-learning madrasah oleh guru yakni aspek kemudahaan untuk digunakan, dan aspek manfaat atau kegunaan pembelajaran e-learning madrasah pada mata pelajaran Biologi. Berikut ini distribusi jawaban yang diperoleh dari angket guru.

Tabel 4. Tabel Perhitungan Presentase Aspek Kemudahan

\begin{tabular}{|c|c|c|c|c|c|c|c|c|}
\hline \multirow[b]{2}{*}{ Indikator Kemudahan } & \multicolumn{6}{|c|}{ Skor } & \multirow{2}{*}{$\begin{array}{l}\text { Persentase } \\
\%\end{array}$} & \multirow{2}{*}{$\begin{array}{c}\text { Rata- } \\
\text { rata } \\
\%\end{array}$} \\
\hline & SS & $\mathbf{S}$ & KS & TS & STS & Total & & \\
\hline $\begin{array}{l}\text { Saya sering berinteraksi dengan peserta didik } \\
\text { melalui e-learning madrasah }\end{array}$ & 0 & 4 & 1 & 0 & 0 & 19 & 76 & \\
\hline $\begin{array}{l}\text { Saya terlibat dalam pembelajaran memalui e- } \\
\text { learing madrasah setidaknya sekali dalam sehari }\end{array}$ & 0 & 5 & 0 & 0 & 0 & 20 & 80 & \\
\hline $\begin{array}{l}\text { Saya mengunggah bahan ajar pada e-learning } \\
\text { madrasah }\end{array}$ & 1 & 4 & 0 & 0 & 0 & 21 & 84 & 80 \\
\hline Saya membuat tes pada $e$-learning madrasaah & 2 & 3 & 0 & 0 & 0 & 22 & 88 & \\
\hline $\begin{array}{l}\text { Saya berinteraaksi dengan pesert didik melalui } e \text { - } \\
\text { learning madrasaah }\end{array}$ & 0 & 3 & 2 & 0 & 0 & 18 & 72 & \\
\hline
\end{tabular}

Tabel 4 menunjukkan bahwa e-learning madrasah memberikan kemudahan guru dalam mengunakan e-learning madrasah hal ini ditunjukkan dengan rat-rta persentase paada aspek kemudahan sebesar $80 \%$. Guru terlibat dalam pemebelajaran dengan peserta didik melalui elearning madrasah setiap hari sehingga dapat dengan mudah berinteraksi dengan peserta didik. Guru juga dapat dengan mudah mengunngah bahan ajar, memberikan tugas, serta tes pada peserta didik. 
EDUTECH : Jurnal Inovasi Pendidikan Berbantuan Teknologi

Vol. 1 No. 2 Agustus 2021, e-ISSN : 2797-0140 | p-ISSN : 2797-0590

Tabel 5 Tabel Perhitungan Presentase Aspek Kegunaan

\begin{tabular}{|c|c|c|c|c|c|c|c|c|}
\hline \multirow[b]{2}{*}{ Indikator Kegunaan } & \multicolumn{6}{|c|}{ Skor } & \multirow{2}{*}{$\begin{array}{l}\text { Persentase } \\
\quad \%\end{array}$} & \multirow{2}{*}{$\begin{array}{l}\text { Rata- } \\
\text { rata \% }\end{array}$} \\
\hline & SS & $\mathbf{S}$ & KS & TS & STS & Total & & \\
\hline $\begin{array}{l}\text { E-learning madrasah membuaat kinerja saya } \\
\text { meningkat }\end{array}$ & 0 & 3 & 2 & 0 & 0 & 18 & 72 & \\
\hline $\begin{array}{l}\text { E-learning madrasah membuat kegiatan belajar } \\
\text { menjadi efektif }\end{array}$ & 0 & 4 & 1 & 0 & 0 & 19 & 76 & \\
\hline E-learning madrasah membuat belajar lebih mudaah & 0 & 5 & 0 & 0 & 0 & 20 & 80 & 79.2 \\
\hline $\begin{array}{l}\text { E-learning madrasah membuat saya nyaman dalam } \\
\text { mengajar }\end{array}$ & 2 & 1 & 2 & 0 & 0 & 20 & 80 & \\
\hline $\begin{array}{l}\text { E-learning madrasah bermanfaat daalam proses } \\
\text { pembelajaran }\end{array}$ & 2 & 3 & 0 & 0 & 0 & 22 & 88 & \\
\hline
\end{tabular}

Tabel 5 memberikan gambaran baahwa aspek kemanfatan atau kegunaan e-learning madrasah dalam pembelajaran daring pada mata pelajaran Biologi cukup baik. Hal ini ditunjukkan dengan rata-rata persentase pada aspek kegunaan atau kebermanfaatan sebesar 79,2\%.

\section{Pembahasan}

E-learning madrasah terdapat banyak fitur seperti video conference, KI (Kompetensi Inti), KD (Kompetensi Dasar), CBT (Computer Based Test), Jurnal Guru, Bahan ajar, dan lain lain sehingga sangat menunjang kelengkapan administrasi guru. Pada penelitin ini juga didapatkan hasil presentase dari aspek kemudahan dan kegunaan yang baik. Artinya $e$-learning madrasah efektif digunakan guru pada pengajaran mata pelajaraan Biologi. Fitur-fitur yang terdapat pada $e$-learning madrasah tersebut juga memberikan pengalaman baru kepada peserta didik. Pada penelitian ini ditunjukkan dengan hasil presentase dari aspek motivasi, kemudahan, dan kegunaan yang dapat dikategorikan baik. Hal ini sejalan dengan Tim Didaktik Metodik Kurikulum dari Institut Keguruan dan Ilmu Pendidikan Surabaya (IKIP Surabaya) atau sekarang telah berganti menjadi UNESA menyatakan bahwa efisiensi dan kefektifan mengajar dalam proses interaksi belajar yang baik adalah segala upaya guru dalam membantu murid agar dapat belajar dengan baik (Trianto, 2009). Pada penelitian ini dapat dikatakan bahwa pembelajaran jarak jauh dalam jaringan (daring) pada mata pelajaran Biologi di MAN 3 Jombang termasuk efektif. Hal ini sesuai dengan pendapat Wicaksono (2011) suatu pembelajaran dikatakan efektif apabila memenuhi ciri-ciri sebagai berikut: a) dapat mengembangkan pemahaman siswa terhadap materi belajar, b) membuat siswa menjadi memiliki rasa ingin tahu, c) membuat siswa menjadi tertantang, d) dapat membuat siswa aktif secara mental, fisik dan psikis, e) membantu siswa tumbuh kreatif, f) mudah dilaksanakan oleh guru.

Penelitian ini didukung oleh penelitian yang dilakukan oleh Sutini, dkk (2020) pembelajaran daring menggunakan e-learning madrasah pada mata pelajaran Matematika dinilai efektif. Sejalan dengan penelitian yang dikemukakan oleh Hikmah (2020) penggunan aplikasi $e$ learning madrasah untuk pembelajaran jarak jauh di MIN 1 Rembang selama bulan Agustus terbukti efektif serta bisa diterima dan diikuti oleh peserta didik.

Faktor pendukung dan penghambat efektivitas pembelajaran jarak jauh dalam jaringan (daring) didapatkan dari data hasil wawancaara terhadap responden yakni peserta didik dan guru. Peserta didik di MAN 3 Jombang sebagian besar bertempat tinggal di pondok dibawah naungan yayasaan Pondok Pesantren Bahrul Ulum. Pondok-pondok tersebut memfasilitaasi santri dengn jaringan internet yang terjadwal agar kegiatan pembelajaran di sekolah dapat diikuti oleh santri. Selain itu pihak sekolah memberikan paket data bagi pesertaa didik maupun guru untuk mendukung pembelajaran jarak jauh dalam jaringan di masa pandemi Covid-19 ini. Faktor lain yang mendukung efektifitas pembelajaran Biologi melalui e learning madrasah adalah tersedianya fitur-fitur yang cukup lengkap pada e-learning madrasah. 
Sedangkan faktor penghambat pembelajaran jarak jauh dalam jaringan (daring) ini adalah jaringan internet yang kurang baik dan adanya pembatasan penggunaan handphone atau laptop di pondok sehingga kurang maksimal dalam belajar. Hambatan yang dialami guru yakni belum bisa maksimal pada pembelajaran Biologi yang memerlukan kegiatan praktikum di laboratorium, sehinggaa siswa tidak dapat mengalami pengalaman langsung pada kegiatan praktikum. Selama materi praktikum dapat dilakukan dirumah, guru memberikn tugas praktikum yang dapat dikerjkan di rumah dengan sederhana. Namun apabila maateri praktikum yang membutuhkan alat laboratorium mak guru hanya mengunggah link video mengenai praktikum tersebut yang ada di Youtube. Adanya faktor penghambat ini, perlu dilakukan evaluasi guna proses pembelajaran dapat berjalan dengan lancar. Menurut Oemar (2005) adanya faktor penghambat dan pendukung untuk mewujudkan suatu tujuan dari pembelajaran yang maksimal. Meskipun dalam pelaksanaannya perlu dilakukan evaluasi agar mendapat langkah perbaikan dengan jelas dan berbasis data.

\section{KESIMPULAN}

Pembelajaran jarak jauh dalam jaringan (daring) melalui e-learning madrasah pada mata pelajaran Biologi menunjukkan bahwa pembelajaran menggunakan e-learning madrasah tergolong efektif. E-learning madrasah sebagai alat yang dapat memfasilitasi peserta didik maupun guru dalam proses pembelajaran di masa pandemi Covid-19. Hal ini dikarenakan banyak pihak yang mendukung pembelajaran ini, namun terdapat beberapa faktor yang dapat menghambat pembelajaran sehingga harus dilakukan evaluasi agar mendapat langkah perbaikan agar pembelajaran dapat berjalan dengan lancar. Perlu juga di lakukan penelitian mengenai hasil belajar peserta didik selama penggunaan $e$ - learning madrasah.

\section{DAFTAR PUSTAKA}

Arikunto, S. (2013). Prosedur Penelitian Suatu Pendekatan Praktik. Jakarta: Rineka Cipta.

Budiyono. (2003). Metodologi Penelitian Pendidikan. Surakarta: UNS Press.

Dimyati \& Mudjiono. (2009). Belajar dan Pembelajaran. Jakarta: Rineka Cipta.

Entika, H.S.A. and Ling, Y.L. (2019). The Importance of Immediate Constructive Feedback on Studentse Instrumental Motivation in Speaking in English. Britain International of Linguistics, Arts and Education (BIoLAE) Journal, 1-7.

Gunawan, H. (2017). Dasar-Dasar Metodologi Penelitian Pendidikan. Bandung: Fakultas

Tarbiyah dan Keguruan UIN Sunan Gunung Djati.

Hayati, N. (2020). Metode Pembelajaran Daring atau E-Learning yang Efektif. Singaraja:

Universitas Pendidikan Ganesha.

Hikmah, S. (2020) Pemanfaatan E-Learning Madrasah Dalam Pelaksanaan Pembelajaran Jarak Jauh Masa Pandemi Di Min 1 Rembang. Edutrained: Jurnal Pendidikan dan Pelatihan, 4(2), 73-85, from DOI : http://doi.org/10.37730/edutrained.v4i2.81

Insiyah, SJ. (2020) E-learning Madrasah Dan Solusi Pembelajaran Di Tengah-tengah Pandemi COVID-19. Kazanah: Jurnal Edukasi, 2(2), 139-147.

Mustakim. (2020). Efektivitas Pembelajaran Daring Menggunakan Media Online Selama Pandemi Covid- 19 Pada Mata Pelajaran Matematika. Al asma: Journal of Islamic Education, 2(1), $1-12$.

Trianto. (2009). Mendesain Model Pembelajaran Inovatif-Progressif: Konsep, Landasan dan Implementasinya Pada KTSP. Jakarta: Kencana Prenadamedia Group.

Oemar, H. (2005). Proses Belajar Mengajar. Jakarta: Bumi Aksara.

Oktavian, R., \& Aldya, R. F. (2020). Efektivitas Pembelajaran Daring Terintegrasi Di Era Pendidikan 4.0. Jurnal Pendidikan dan Ilmu Pengetahuan, 20(2), 129-135. 
Purwantoro, A., Asari, S., \& Maruf, N. (2021). The Effectiveness of E-Learning Madrasah in English Teaching. Budapest International Research and Critics Institute-Journal (BIRCIJournal), 4(3), 5234-5244, from DOI: https://doi.org/10.33258/birci.v4i3.2314.

Sutini, Mushofan, M., Ilmia, A., Yanti, AD., Rizky, AN., \& Lailiyah, S. (2020) Efektivitas Pembelajaran Daring Dengan Menggunakan E-Learning Madrasah Terhadap Optimalisasi Pemahaman Matematika Siswa. JRPM (Jurnal Review Pembelajaran Matematika), 5(2), 124-136, from DOI: https://doi.org/10.15642/jrpm.2020.5.2.124-136.

Wicaksono. (2011). Efektivitas Metode Pembelajaran. Jakarta: Wordpress. (Jenis: buku author sama dengan penerbit) 